\title{
ANALISIS EFISIENSI PEMASARAN JAGUNG (Zea mays) DI KABUPATEN WONOGIRI
}

\author{
Dea Arien Alinda Dewi ${ }^{1}$, Darsono ${ }^{2}$, Agustono $^{3}$ \\ ${ }^{1}$ Program Studi Agribisnis Universitas Sebelas Maret \\ ${ }^{2}$ Program Studi Agribisnis Universitas Sebelas Maret \\ ${ }^{3}$ Program Studi Agribisnis Universitas Sebelas Maret \\ Email korespondensi: deaarienalindadewi@gmail.com
}

\begin{abstract}
This study aims to determine the market structure, behavior and performance of maize marketing in Wonogiri District. The basic research method is analytical descriptive. The research location was chosen purposively. The farmers sample were determined by using quota sampling, while traders sample were chosen by using snowball sampling method. The research data is analyzed by SCP approach (Structure, Conduct, and Performance of Market). The research results showed that the market structure of maize in Wonogiri District leads to the incomplete market competition, namely oligopsony market. This market structure causes the inefficient market. The market conduct is inefficient, it is showed by the $\beta 1(0.785)<1$. There are four types of maize marketing channel in Wonogiri District with the farmer's share more than $50 \%$. It indicates that the maize marketing in Wonogiri District is included in efficient category.

Keywords: marketing efficiency, marketing margins, price transmission elasticity, SCP (structure, conduct, and performance)
\end{abstract}

\section{INTISARI}

Penelitian ini bertujuan untuk mengetahui struktur pasar, perilaku pasar serta kinerja pasar jagung di Kabupaten Wonogiri. Metode dasar penelitian adalah deskriptif analitis. Penentuan lokasi penelitian dilakukan secara purposive atau sengaja. Metode pengambilan sampel petani menggunakan metode quota sampling, dengan jumlah sampel petani sebanyak 30 responden. Metode pengambilan sampel pedagang menggunakan metode snowball sampling. Data dianalisis dengan metode SCP (Structure, Conduct and Performance). Hasil penelitian menunjukkan bahwa struktur pasar jagung di Kabupaten Wonogiri mempunyai kecenderungan pada pasar persaingan tidak sempurna yaitu pasar oligopsoni. Struktur ini mengakibatkan pasar tidak efisien. Perilaku pasar (market conduct) ditunjukkan oleh $\beta_{1}(0,785)<1$ sehingga pasar tidak efisien. Kegiatan pemasaran jagung di Kabupaten Wonogiri meliputi 4 tipe saluran pemasaran dengan yang mempunyai farmer'share $>50 \%$. Hal ini menunjukkan bahwa pemasaran jagung di Kabupaten Wonogiri termasuk dalam kategori efisien.

Kata kunci: efisiensi pemasaran, elastisitas transmisi harga, marjin pemasaran, SCP (struktur, perilaku dan kinerja pasar)

\section{PENDAHULUAN}

Indonesia merupakan negara agraris karena memiliki sektor pertanian, perikanan dan kehutanan yang besar sehingga sangat berpengaruh terhadap perekonomian bangsa. Sektor pertanian, perikanan dan kehutanan memegang peranan yang sangat penting dalam perekonomian Indonesia, baik sebagai sumber pertumbuhan, lapangan kerja, pendapatan maupun sumber devisa negara. Sektor pertanian, perikanan dan kehutanan hingga saat ini masih menjadi sektor andalan bagi bangsa Indonesia karena kebanyakan dari penduduk Indonesia mempunyai mata pencaharian di bidang pertanian, perikanan dan kehutanan.

Sub sektor tanaman bahan makanan mencakup tanaman padi, palawija, dan hortikultura (BPS, 2015). Menurut Tangendjaja dan Wina (2011), jagung merupakan 
ISSN : 2621-3974 (online)

Volume 01, Number 02 (2018)

ISSN : 2622-6154 (print)

tanaman pangan dengan tingkat kepentingan kedua setelah padi dan merupakan sumber utama karbohidrat jetelah jagung. Menurut Tangendjaja et al (2005) produksi jagung Indonesia diutamakan sebagai makanan manusia. Akan tetapi ketika industri unggas mulai berkembang yang disertai dengan meningkatnya produksi beras, maka pemanfaatan jagung secara bertahap sedikit bergeser ke pakan (makanan ternak).

Provinsi Jawa Tengah merupakan salah satu provinsi yang memiliki luas lahan pertanian yang besar sehingga produksi pertanian menjadi salah satu yang patut diperhitungkan. Produksi jagung di Jawa Tengah pada tahun 2015 sebesar 3.212.391 ton dengan luas panen sebesar 542.804 hektar (BPS, 2015). Besarnya produksi jagung di Jawa Tengah tidak lepas dari peran daerah atau kabupaten penyangga produksi jagung salah satunya Kabupaten Wonogiri. Produksi jagung di Kabupaten Wonogiri adalah produksi terbesar kedua di Provinsi Jawa Tengah yaitu sebesar 327.710 ton dengan luas panen sebesar 53.598 ha. Produtivitas jagung di Kabupaten Wonogiri sebesar 61,14 kw/ha (BPS, 2016)

Tabel 1. Harga Jagung Pada Tingkat Produsen, Konsumen dan Marjin Pemasaran Jagung di Kabupaten Wonogiri Tahun 2012-2017

\begin{tabular}{cccc}
\hline Tahun & $\begin{array}{c}\text { Harga Jagung Tingkat } \\
\text { Produsen }(\mathbf{R p})\end{array}$ & $\begin{array}{c}\text { Harga Jagung Tingkat } \\
\text { Konsumen }(\mathbf{R p})\end{array}$ & $\begin{array}{c}\text { Marjin } \\
(\mathbf{R p})\end{array}$ \\
\hline 2012 & $2.400,42$ & $3.107,67$ & 707,25 \\
2013 & $3.087,73$ & $3.730,08$ & 642,35 \\
2014 & $3.027,18$ & $3.856,75$ & 829,57 \\
2015 & $3.073,34$ & $3.840,64$ & 767,30 \\
2016 & $3.426,81$ & $4.497,74$ & $1.070,93$ \\
2017 & $3.782,38$ & $5.047,84$ & $1.265,46$ \\
\hline
\end{tabular}

Sumber: Dinas Pertanian Kabupaten Wonogiri (diolah), 2012-2017

Berdasarkan Tabel 1. dapat diketahui besarnya harga jagung di tahun 2012 hingga tahun 2017 di tingkat produsen maupun harga di tingkat konsumen serta besarnya marjin pemasarannya. Harga jagung di tingkat produsen dari tahun 2012 hingga tahun 2017 cenderung meningkat, begitupun harga di tingkat konsumen juga cenderung meningkat. Menurut Tabel 3. dapat diketahui pula bahwa besarnya marjin pemasaran dari tahun 2012 hingga tahun 2017 juga semakin meningkat hal ini menunjukkan bahwa share yang diterima petani semakin rendah.

Berdasarkan Tabel 1. dapat disimpulkan bahwa besarnya harga di tingkat produsen dan konsumen dari tahun 2012 hingga tahun 2017 cenderung meningkat, namun besarnya kenaikan harga di tingkat konsumen lebih tinggi dibanding kenaikan harga di tingkat produsen. Hal tersebut yang mempengaruhi besarnya marjin pemasaran karena semakin tinggi harga di tingkat konsumen yang tidak diimbangi dengan tingginya kenaikan harga di tingkat produsen membuat marjin pemasaran semakin tinggi. Berdasarkan hal tersebut dapat diketahui bahwa share yang diterima petani rendah. Hal ini juga menyebabkan petani menjadi tidak memiliki daya tawar terhadap produknya sehingga posisi tawar petani menjadi rendah.Efisiensi pemasaran diduga dipengaruhi oleh struktur pasar, perilaku pasar serta kinerja pasar. Di dalam kegiatan pemasaran jagung tentunya dilakukan oleh penjual dan pembeli dengan jumlah tertentu, terdapat pula hambatan masuk pasar (barrier to entry), kemampuan penetapan harga, dan jenis produk yang 
ISSN : 2621-3974 (online)

Volume 01, Number 02 (2018)

ISSN : 2622-6154 (print)

diperjual belikan dalam kegiatan pemasaran. Berdasarkan hal tersebut maka dapat dilihat struktur pasar yang terjadi dalam pemasaran jagung yang ada di Kabupaten Wonogiri. Perbedaan saluran pemasaran akan mengakibatkan perbedaan harga jagung di tingkat petani. Sering kali dalam kegiatan pemasaran jagung, petani hanya sebagai penerima harga. Hal tersebut menunjukkan bahwa terdapat perilaku tertentu dari suatu lembaga pemasaran sehingga dapat diketahui perilaku pasar dalam pemasaran jagung. Perbedaan saluran pemasaran juga akan berdampak pada perbedaan marjin pemasaran serta besarnya share yang diterima oleh petani yang kemudian dari hal tersebut dapat diketahui kinerja pasar dalam pemasaran jagung. Berdasarkan latar belakang tersebut yang mendasari penulis untuk meneliti bagaimana efisiensi pemasaran jagung di Kabupaten Wonogiri.Tujuan dari penelitian analisis efisiensi pemasaran jagung (Zea mays) di Kabupaten Wonogiri ini yaitu mengetahui struktur pasar, perilaku pasar dan kinerja pasar jagung di Kabupaten Wonogiri.

\section{METODE PENELITIAN}

\section{Metode Dasar Penelitian}

Metode dasar yang digunakan dalam penelitian ini adalah metode deskriptif analitis. Menurut Ode (2012) metode deskriptif analitis adalah prosedur pemecahan masalah yang diselidiki dengan menggambarkan atau melukiskan keadaan subjek atau objek penelitian seseorang, lembaga masyarakat, dan lain-lain. Pelaksanaan penelitian ini dengan menggunakan teknik survei, yaitu cara pengumpulan data penelitian dengan mengambil sejumlah sampel dari suatu populasi dan menggunakan kuisioner yang memuat daftar pertanyaan sebagai alat pengumpulan data yang pokok (Singarimbun dan Efendi, 2006).

\section{Metode Penentuan Lokasi}

Penentuan lokasi penelitian dilakukan secara purposive (sengaja), yaitu berdasarkan pertimbangan-pertimbangan tertentu sesuai dengan tujuan penelitian (Singarimbun dan Efendi, 2006). Kabupaten Wonogiri sebagai lokasi penelitian kemudian dipilih lima kecamatan sampel yaitu Kecamatan Pracimantoro, Giriwoyo, Batuwarno, Eromoko dan Ngadirojo.

\section{Metode Analisis Data}

\section{Struktur Pasar}

Struktur pasar dianalisis secara deskriptif dengan menganalisis karakteristik jumlah penjual atau pembeli, hambatan keluar masuk pasar, kemampuan penetapan harga serta jenis produk yang diperjual belikan.

Tabel 2. Tipe-tipe Struktur Pasar

\begin{tabular}{lllll}
\multicolumn{1}{c}{$\begin{array}{c}\text { Struktur } \\
\text { Pasar }\end{array}$} & $\begin{array}{l}\text { Jumlah } \\
\text { Penjual/ } \\
\text { Pembeli }\end{array}$ & Hambatan & $\begin{array}{c}\text { Kemampuan } \\
\text { Penetapan } \\
\text { Harga }\end{array}$ & Jenis Produk \\
\hline $\begin{array}{l}\text { Persaingan } \\
\text { sempurna }\end{array}$ & $\begin{array}{l}\text { Penjual: } \\
\text { Banyak }\end{array}$ & $\begin{array}{l}\text { Tidak ada } \\
\text { (sangat mudah) }\end{array}$ & $\begin{array}{l}\text { Tidak ada }(\text { price } \\
\text { taker) }\end{array}$ & Homogen \\
\hline \hline
\end{tabular}


ISSN : 2622-6154 (print)

\begin{tabular}{|c|c|c|c|c|}
\hline Monopoli & $\begin{array}{l}\text { Penjual: } \\
\text { Tunggal }\end{array}$ & $\begin{array}{l}\text { Ada (sangat } \\
\text { sulit) }\end{array}$ & $\begin{array}{l}\text { Sangat besar } \\
\text { (price maker) }\end{array}$ & $\begin{array}{l}\text { Produknya } \\
\text { unik/khas }\end{array}$ \\
\hline $\begin{array}{l}\text { Persaingan } \\
\text { Monopolistik }\end{array}$ & $\begin{array}{l}\text { Penjual: } \\
\text { Beberapa }\end{array}$ & $\begin{array}{l}\text { Tidak ada } \\
\text { (relatif mudah) }\end{array}$ & Sedikit & Terdiferensiasi \\
\hline Oligopoli & $\begin{array}{l}\text { Penjual: } \\
\text { Beberapa }\end{array}$ & Cukup besar & $\begin{array}{l}\text { Dengan kerja } \\
\text { sama: sangat } \\
\text { besar } \\
\text { Tanpa Kerja } \\
\text { sama: sedikit }\end{array}$ & $\begin{array}{l}\text { Homogen dan } \\
\text { Terdiferensiasi }\end{array}$ \\
\hline Monopsoni & $\begin{array}{l}\text { Pembeli } \\
\text { satu }\end{array}$ & $\begin{array}{l}\text { Ada (sangat } \\
\text { sulit) }\end{array}$ & $\begin{array}{l}\text { Sangat besar } \\
\text { (price maker) }\end{array}$ & Homogen \\
\hline Oligopsoni & $\begin{array}{l}\text { Pembeli: } \\
\text { Beberapa }\end{array}$ & Cukup besar & $\begin{array}{l}\text { Dengan kerja } \\
\text { sama: sangat } \\
\text { besar } \\
\text { Tanpa kerja sama: } \\
\text { sedikit }\end{array}$ & $\begin{array}{l}\text { Homogen dan } \\
\text { terdiferensiasi }\end{array}$ \\
\hline
\end{tabular}

Sumber : Arifin (2007)

\section{Perilaku Pasar}

Analisis elastisitas transmisi harga digunakan untuk mengetahui perilaku pasar (Market Conduct) di Kabupaten Wonogiri. Menurut Sudiyono (2001) elastisitas transmisi harga dapat ditentukan dengan rumus sebagai berikut :

$\mathrm{Et}=\frac{\partial \mathrm{Pr}}{\partial \mathrm{Pf}} \times \frac{\mathrm{Pf}}{\mathrm{Pr}}$

Analisis regresi linear sederhana digunakan untuk menganalisis hubungan linear antara 1 variabel bebas (independent) dan 1 variabel bergantung/terikat (dependent). Karena harga di tingkat petani jagung (Pf) linier terhadap harga di tingkat konsumen (Pr), atau secara matematis jika di transformasikan dalam bentuk linear menjadi : LnPf $=\operatorname{Ln} \beta_{0}+\beta_{1} \operatorname{Ln} \operatorname{Pr}$

Keterangan :

Et adalah elastisitas transmisi harga, $\beta_{0}$ adalah intersep (titik potong), $\beta_{1}$ adalah koefisien regresi atau elastisitas, Pf adalah harga di tingkat petani jagung (produsen), Pr adalah harga di tingkat konsumen

Menurut Azzaino (1982) yaitu sebagai berikut; (a) Jika $\beta_{1}<1$, artinya perubahan harga $1 \%$ di tingkat konsumen akan mengakibatkan perubahan harga yang kurang dari $1 \%$ di tingkat produsen. (b) Jika Jika $\beta_{1}=1$, artinya perubahan harga $1 \%$ di tingkat konsumen akan mengakibatkan perubahan harga $1 \%$ di tingkat produsen. (c) Jika $\beta_{1}>$ 1 , artinya perubahan harga $1 \%$ di tingkat konsumen akan mengakibatkan perubahan harga lebih dari $1 \%$ di tingkat produsen.

Menurut Yuniarti (2009) Elastisitas transmisi harga untuk hasil - hasil pertanian biasanya bernilai kurang dari satu $(\beta<1)$, artinya perubahan harga $1 \%$ ditingkat konsumen akan mengakibatkan perubahan ditingkat produsen yang kurang dari $1 \%$, (pasar berjalan tidak efisien). $\beta=1$ (pasar berjalan efisien). $\beta>1$, pasar tidak efisien.

Menurut Sudiyono (2001) persentase marjin pemasaran serta farmer's share dirumuskan sebagai berikut :

$\mathrm{Mp}=\left(\frac{\mathrm{Pr}-\mathrm{Pf}}{\mathrm{Pr}}\right) \times 100 \%$

Keterangan : 
ISSN : 2622-6154 (print)

Mp adalah marjin pemasaran jagung (\%), Pf adalah harga jagung di tingkat produsen $(\mathrm{Rp} / \mathrm{Kg})$, Pr adalah harga jagung di tingkat konsumen $(\mathrm{Rp} / \mathrm{kg})$.

$\mathrm{F}=\left(1-\frac{\mathrm{Mp}}{\mathrm{Pr}}\right) \times 100 \%$

Keterangan :

$\mathrm{F}$ adalah bagian yang diterima jagung (\%), $\mathrm{M}$ adalah marjin pemasaran jagung $(\mathrm{Rp} / \mathrm{Kg})$, Pr adalahharga jagung di tingkat konsumen $(\mathrm{Rp} / \mathrm{Kg})$.

\section{HASIL DAN PEMBAHASAN}

\section{Karakteristik Petani Responden}

Tabel 3. Identitas Responden Petani

\begin{tabular}{lc}
\hline \multicolumn{1}{c}{ Keterangan } & Jumlah \\
\hline Umur (tahun) & $46-55$ \\
Jumlah anggota keluarga (orang) & $5-8$ \\
Tingkat pendidikan & \\
a. Tidak tamat SD & 4 \\
b. Tamat SD & 12 \\
c. Tamat SMP & 9 \\
d. Tamat SMA/SMK & 5 \\
Lama usahatani (tahun) & $25-29$ \\
Luas Lahan (ha) & 0,5 \\
\hline
\end{tabular}

Sumber: Analisis Data Primer, 2018

Berdasarkan Tabel 3. dapat diketahui bahwa umur petani responden paling banyak pada kelompok masa lansia awal (umur 46-55 tahun) Rata-rata jumlah anggota petani responden sebanyak 5-8 orang. Petani responden memiliki tingkat pendidikan rendah karena paling banyak petani responden berada di jenjang pendidikan SD. Lahan yang dimiliki petani cenderung sempit yaitu $<0,5$ ha.

Pengalaman usahatani petani responden yaitu antara 25-29 tahun. Menurut Sinaga dan Novia (2016) pengalaman berusahatani memegang peranan penting dalam proses usahatani. Pengalaman petani dalam berusaha tani merupakan salah satu faktor yang menentukan pengambilan keputusan. Suatu kegiatan usahatani didalam pengelolaannya tidak lepas dari penentuan keputusan-keputusan yang akan diambil untuk pengelolaan dan kelangsungan usaha tersebut. Apabila pengalaman yang dimiliki petani semakin banyak, maka akan dapat mendorong petani untuk menerapkan teknologi baru yang berguna untuk mendapatkan hasil yang lebih baik.

\section{Karakteristik Pedagang Sampel}

Tabel 4. Identitas Responden Pedagang

\begin{tabular}{lc}
\multicolumn{1}{c}{ Keterangan } & Jumlah \\
\hline Jumlah pedagang yang terlibat dalam saluran pemasaran & 13 \\
Rata-rata umur (tahun) & 49 \\
Tingkat pendidikan & \\
a. Tamat SD & 0 \\
b. Tamat SMP & 7 \\
\hline \hline
\end{tabular}




\begin{tabular}{cc}
\hline \hline c. $\quad$ Tamat SMA/SMK & 4 \\
d. Sarjana & 2 \\
Rata-rata pengalaman usaha (tahun) & 25 \\
\hline
\end{tabular}

\section{Sumber: Analisis Data Primer, 2018}

Berdasarkan Tabel 4. dapat diketahui bahwa terdapat responden pedagang sebanyak 13 orang yang terlibat dalam pemasaran jagung di Kabupaten Wonogiri yang terbagi menjadi 2 pedagang pengumpul desa, 5 pedagang pengumpul kecamatan, dan 6 pedagang besar dengan rata-rata umur 49 tahun. Pada usia tersebut tergolong dalam kategori usia lansia awal yang artinya memungkinkan pedagang mulai sulit menerima perkembangan teknologi dan inovasi sehingga sulit untuk mendorong kemajuan usahanya. Tingkat pendidikan pedagang sampel tergolong lebih baik apabila dibandingkan dengan petani sampel yaitu rata-rata pendidikan paling banyak yaitu pada tingkat SMP sebanyak 7 orang atau sebesar 53,85\%. Pedagang sampel memiliki rata-rata lama usaha selama 25 tahun. Lama usaha juga mempengaruhi pengalaman pedagang dalam mengatasi faktor-faktor yang menjadi penghambat dalam kegiatan pemasaran jagung seperti persaingan dalam mencari barang (jagung), persaingan dalam mencari pembeli, serta masalah lain yang sering terjadi dalam kegiatan pemasaran.

\section{Struktur Pasar}

Tabel 5. Karakteristik Struktur Pasar

\begin{tabular}{clc}
\hline No & \multicolumn{1}{c}{ Karakteristik } & Uraian \\
\hline 1 & Jumlah Penjual & 30 \\
2 & Jumlah Pembeli & 13 \\
3 & Hambatan Masuk Pasar & Ada \\
4 & Penetapan Harga & Petani sebagai price taker \\
5 & Jenis Produk & Homogen \\
\hline
\end{tabular}

Sumber: Analisis Data Primer, 2018

Berdasarkan Tabel 5. dapat disimpulkan bahwa sesuai dengan karakteristik tersebut maka struktur pasar jagung yang ada di Kabupaten Wonogiri terdapat kecenderungan yang mengarah pada pasar persaingan tidak sempurna yaitu pasar oligopsoni sehingga pemasaran jagung termasuk dalam kategori tidak efisien

\section{Perilaku Pasar}

Uji heteroskedastisitas dilihat berdasarkan diagram scatterplot yang menunjukkan bahwa titik-titik yang ada dalam diagram terlihat mengumpul. Hal ini menunjukkan bahwa terdapat kemungkinan terjadinya heteroskedastisitas pada model regresi. Menindaklanjuti hal tersebut maka dilakukan uji glejser. Uji glejser dilakukan dengan cara meregresikan antara variabel bebas dengan nilai absolut residualnya. Berdasarkan pengujian yang telah dilakukan, diketahui bahwa besarnya signifikasi antara variabel bebas dengan absolut residual sebesar 0,650>0,05 maka dapat disimpulkan bahwa tidak terjadi heteroskedastisitas dalam model.

Berdasarkan hasil uji autokorelasi yang dilakukan, diperoleh nilai DW sebesar 1,687. Berdasarkan ketentuan diatas dapat diketahui bahwa 1,65 < DW $(1,686)<2,35$ sehingga dapat disimpulkan bahwa tidak terjadi autokorelasi dalam model regresi.

Tujuan uji normalitas adalah untuk mengetahui apakah distribusi sebuah data mengikuti atau mendekati distribusi normal, yakni distribusi data dengan bentuk lonceng 
ISSN : 2621-3974 (online)

Volume 01, Number 02 (2018)

ISSN : 2622-6154 (print)

(bell shoped) (Santoso, 2010). Berdasarkan grafik normal P-Plot menunjukkan bahwa sebaran data mendekati garis diagonal. Sehingga menunjukkan bahwa sebaran data tersebut terdapat dalam keserasian antara variabel terikat dengan variabel bebas, serta sampel berada pada sebaran garis estimasi.

Koefisien determinasi $\left(\mathrm{R}^{2}\right)$ digunakan untuk mengukur seberapa baik garis regresi sesuai dengan data aktualnya (goodness of fit) (Widarjono, 2010). Besarnya koefisiensi regresi $\left(R^{2}\right)$ sebesar 0,755 . Nilai $R^{2}$ menunjukkan bahwa sebesar $75,5 \%$ variasi variabel harga jagung di tingat produsen $(\mathrm{Pf})$ dapat dijelaskan oleh variabel independent yang digunakan dalam model yaitu variabel harga rata-rata jagung di tingkat konsumen (Pr) Sedangkan sisanya sebesar $24,5 \%$ dijelaskan oleh variabel lain di luar model.

Uji statistik t pada dasarnya menunjukkan seberapa jauh pengaruh satu variabel independen terhadap variabel dependen dengan menganggap variabel independen lainnya konstan (Ghozali, 2014). besarnya signifikasi harga jagung di tingkat konsumen (Pr) adalah sebesar 0,000 lebih kecil dari $\alpha$ sebesar 0,05 menunjukkan bahwa $\mathrm{H} 0$ ditolak dan H1 diterima. Berarti variabel harga jagung (Pr) di tingkat konsumen secara individu berpengaruh nyata dan memiliki hubungan yang positif terhadap harga di tingkat petani jagung (Pf).

Menurut Irawan (2007) transmisi harga yang rendah mencerminkan tidak efisiensi karena hal itu menunjukkan bahwa perubahan harga yang terjadi di tingkat konsumen tidak seluruhnya diteruskan kepada produsen atau transmisi harga berlangsung secara tidak sempurna. Berdasarkan hasil analisis yang dilakukan maka nilai elastisitas transmisi harga tersebut menunjukkan bahwa apabila terjadi perubahan harga $1 \%$ di tingkat konsumen maka akan mengakibatkan perubahan harga yang kurang dari 1\% atau sebesar $0,785 \%$ di tingkat produsen. Keadaan ini menunjukkan bahwa perubahan harga di tingkat konsumen lebih besar karena pembeli berlaku sebagai penentu harga sedangkan petani jagung hanya sebagai penerima harga sehingga harga di tingkat petani jagung lebih fluktuatif apabila dibanding dengan harga di tingkat konsumen. Hal tersebut dapat disebabkan karena berbagai hal seperti kondisi atau sifat produk pertanian yang mudah rusak maka tidak memungkinkan petani untuk menyimpannya terlalu lama, jagung hanya dapat bertahan \pm 2 bulan dalam kondisi kering sempurna sehingga petani harus cepat menjual hasil panennya (jagung) tanpa mempertimbangkan harga jagung pada saat itu. Karena apabila menunggu harga naik untuk menjual jagung, hal tersebut akan merugikan petani karena kualitas jagung akan menurun jika disimpan terlalu lama yang menyebabkan harga jagung menjadi lebih rendah.

Produk petanian biasanya diproduksi dalam jumlah yang banyak dan homogen sehingga petani tidak memiliki daya tawar terhadap produknya karena apabila petani menaikkan harga maka pembeli akan membeli produk dari petani yang lain. Selain itu, petani juga memiliki kebutuhan yang mendesak, maka untuk memenuhi kebutuhannya tersebut petani akan segera menjual jagungnya tanpa mempertimbangkan harga. Adapun faktor lain seperti kurangnya informasi harga yang diterima oleh petani. Di era modern sekarang ini, seharusnya petani mulai belajar teknologi yang sedang berkembang demi keberlangsungan pemasaran produknya. Seharusnya petani memanfaatkan internet untuk mencari tahu harga jagung yang sedang berkembang di pasar agar petani bisa mendapatkan harga yang sesuai dan lebih menguntungkan.

\section{Kinerja Pasar}

Sebagian besar petani jagung di Kabupaten Wonogiri merupakan petani pemilik penggarap. Lahan yang dimiliki yaitu cenderung lahan sempit $(<0,5 \mathrm{ha})$ yang lokasinya 
ISSN : 2621-3974 (online)

ISSN : 2622-6154 (print)

Volume 01, Number 02 (2018)

berdekatan dengan tempat tinggal. Kondisi lahan yang ada merupakan lahan kering serta sistem pengairan yang tersedia juga kurang baik sehingga sebagian besar petani jagung di Kabupaten Wonogiri menggunakan sistem tadah hujan yang sangat bergantung pada kondisi cuaca. Petani jagung melakukan kegiatan budidaya dengan melakukan pengolahan lahan, penanaman, penyiangan, pemupukan, pemanenan, pembersihan, pengeringan serta pemipilan. Varietas yang banyak digunakan di daerah ini yaitu varietas hibrida Bisi-2. Benih hibrida digunakan oleh petani karena memiliki keunggulan dalam jumlah produksinya yaitu dapat menghasilkan jumlah produksi yang tinggi, namun hal tersebut juga dipengaruhi oleh perawatan yang dilakukan petani serta kondisi lahan yang digunakan dalam kegiatan budidaya.

Setelah dilakukan panen, petani membersihkan jagung dari kulit luarnya. Kegiatan ini masih dilakukan secara manual. Kemudian, setelah jagung dalam keadaan bersih dari kulit luar maka tahap selanjutnya yaitu pengeringan. Kegiatan ini bertujuan agar jagung lebih mudah ketika dipipil. Proses pengeringan jagung dilakukan secara manual sehingga sangat tergantung pada kondisi cuaca, jika cuaca mendukung maka proses pengeringan tidak akan membutuhkan waktu yang lama ( \pm 3 hari). Apabila jagung sudah kering kemudian jagung dipipil secara manual dengan menggunakan tangan. Setelah jagung dipipil, jagung yang dianggap kurang kering maka akan kembali dijemur hingga mencapai tingkat kadar air $\pm 10-12 \%$.

Setelah jagung dipipil maka petani akan menjual jagung kepada pedagang pengumpul desa, pedagang pengumpul kecamatan atau pedagang besar yang sudah menjadi langganan petani untuk menjual hasil panennya. Petani mengemas dan menjual jagung dalam bentuk karung dengan kapasitas $\pm 60 \mathrm{~kg}$ per karung. Harga jagung berfluktuasi setiap hari yaitu berkisar antara Rp. 3.000,00 hingga Rp. 3.150,00 di tingkat petani. Varietas yang dijual tidak berpengaruh terhadap harga, karena perbedaan harga yang diterima petani dipengaruhi oleh tingkat kadar air pada jagung. Sistem pembayaran jagung yang dilakukan dalam kegiatan pemasaran baik pada pedagang pengumpul desa, pedagang pengumpul kecamatan atau pedagang besar yaitu menggunakan sistem pembayaran cash atau tunai.

Kegiatan pemasaran jagung di Kabupaten Wonogiri berpusat di Kecamatan Pracimantoro, hal tersebut didukung oleh besarnya produksi jagung di Kecamatan Pracimantoro yang merupakan daerah sentra produksi jagung terbesar kedua di Kabupaten Wonogiri dengan jumlah produksi sebesar 47.827 ton pada tahun 2016 (BPS, 2017). Selain itu, Kecamatan Pracimantoro memiliki kondisi wilayah yang lebih strategis untuk dijadikan sebagai pusat pemasaran serta didukung oleh pasar yang dimiliki. Kondisi pasar di Kecamatan Pracimantoro merupakan pasar yang lebih maju jika dibanding dengan pasar di Kecamatan Giriwoyo. Sedangkan produksi jagung terkonsentrasi di Kecamatan Giriwoyo, hal ini ditunjukkan oleh besarnya produksi jagung di Kecamatan Giriwoyo sebagai kecamatan yang menghasilkan produksi jagung terbesar di Kabupaten Wonogiri yaitu sebesar 51.261 ton pada tahun 2016.

Pada kegiatan pemasaran jagung terdapat berbedaan volume pembelian pada tiap tingkat lembaga pemasaran. Volume pembelian jagung oleh pedagang pengumpul desa berkisar antara $50 \mathrm{~kg}-200 \mathrm{~kg}$ dalam satu kali transaksi. Keterbatasan modal yang dimiliki oleh pedagang pengumpul desa yang membuat pedagang pengumpul desa tidak dapat melakukan transaksi dengan volume pembelian yang besar. Pedagang pengumpul desa juga hanya membeli jagung di daerah atau desa yang menjadi tempat tinggalnya. Pada pedagang pengumpul kecamatan, volume pembelian jagung berkisar antara $200 \mathrm{~kg}$ $-1.000 \mathrm{~kg}$ dalam satu kali transaksi. Biasanya satu pedagang pengumpul kecamatan dapat 
ISSN : 2621-3974 (online)

Volume 01, Number 02 (2018)

ISSN : 2622-6154 (print)

menguasai beberapa kecamatan yang ada di Kabupaten Wonogiri sehingga pedaganng pengumpul kecamatan tidak hanya membeli jagung dari wilayah kecamatan tempat tinggalnya.Pada pedagang besar, volume pembelian jagung berkisar $>1.000 \mathrm{~kg}$ dalam satu kali transaksi. Hal ini disebabkan karena pedagang besar sudah memiliki modal yang besar sehingga dapat melakukan transaksi dengan volume pembelian yang besar. Biasanya pedagang besar membeli jagung dari wilayah Kabupaten Wonogiri maupun daerah yang berada di luar Kabupaten Wonogiri.

Pada penelitian ini, dapat diketahui terdapat beberapa pola saluran pemasaran jagung di Kabupaten Wonogiri. Tipe-tipe saluran pemasaran tersebut disajikan dalam bagan berikut

ini:

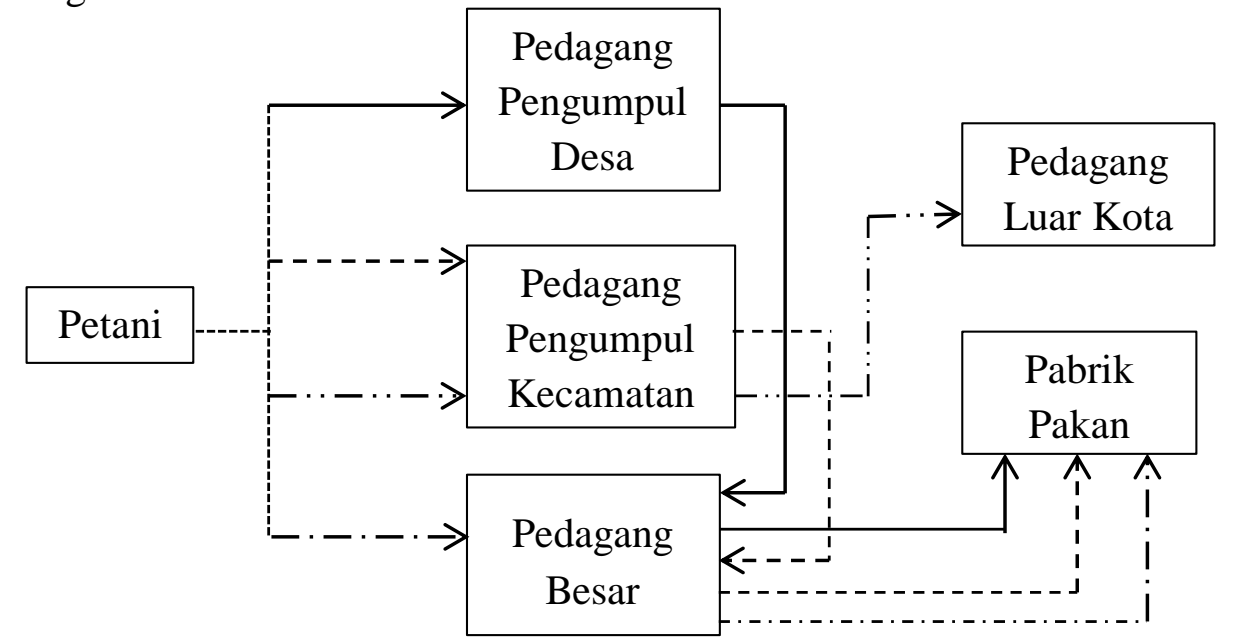

Gambar 1. Saluran Pemasaran Jagung di Kabupaten Wonogiri

Keterangan :

$\begin{array}{ll}\longrightarrow & : \text { Saluran Pemasaran 1 } \\ ------\rightarrow & : \text { Saluran Pemasaran 2 } \\ -\cdot-\cdots-\rightarrow & \text { : Saluran Pemasaran 3 } \\ -\cdot-\cdot-\cdot \rightarrow & \text { : Saluran Pemasaran } 4\end{array}$

Tabel 6. Jumlah dan Persentase Petani dalam Saluran Pemasaran

\begin{tabular}{lcc}
\hline \multicolumn{1}{c}{ Saluran Pemasaran } & Jumlah Petani & Persentase (\%) \\
\hline Saluran 1 & 3 & 10,00 \\
Saluran 2 & 10 & 33,33 \\
Saluran 3 & 5 & 16,67 \\
Saluran 4 & 12 & 40,00 \\
\hline Jumlah & 30 & 100,00 \\
\hline
\end{tabular}

Sumber: Analisis Data Primer, 2018

Berdasarkan Tabel 6. dapat diketahui bahwa pada saluran 4 sebesar $40 \%$ atau digunakan oleh petani sebanyak 12 orang merupakan saluran yang paling banyak digunakan dalam pemasaran jagung di Kabupaten Wonogiri. Sedangkan pada saluran 1 sebesar $10 \%$ atau sebanyak 3 petani merupakan saluran yang paling sedikit digunakan oleh petani jagung. Pada saluran 2 dan 3 masing-masing sebesar 33,33\% dan 16,67\% atau sebanyak 10 petani dan 5 petani menggunakan saluran ini dalam kegiatan pemasarannya. Saluran pemasaran 4 banyak digunakan oleh petani jagung karena dalam saluran ini dianggap sebagai cara yang termudah dalam memasarkan jagungnya dan mendapatkan penghasilan yang sesuai menurut petani karena para petani sudah terbiasa menjual 
ISSN : 2621-3974 (online)

Volume 01, Number 02 (2018)

ISSN : 2622-6154 (print)

jagungnya kepada pedagang besar tersebut. Pada saluran 4 yaitu petani langsung menjual jagungnya kepada pedagang besar sehingga tidak perlu melalui pedagang perantara lainnya.

Tabel 7. Perbedaan Total Marjin Pemasaran, Persentase Marjin Pemasaran dan Farmer's Share Pada 4 Saluran Pemasaran Jagung di Kabupaten Wonogiri

\begin{tabular}{cccc}
\hline Saluran & $\begin{array}{c}\text { Total Marjin } \\
\text { Pemasaran (Rp) }\end{array}$ & $\begin{array}{c}\text { Persentase Marjin } \\
\text { Pemasarann(\%) }\end{array}$ & Farmer's share $(\%)$ \\
\hline 1 & 300,00 & 8,96 & 91,05 \\
2 & 270,00 & 8,11 & 91,89 \\
3 & 200,00 & 6,12 & 93,88 \\
4 & 191,67 & 5,85 & 94,15 \\
\hline
\end{tabular}

Sumber: Analisis Data Primer, 2018

Menurut Ramkumar (2001) apabila dalam saluran pemasaran memiliki bagian yang diterima petani dari harga yang dibayarkan konsumen tinggi serta saluran pemasaran degan biaya pemasaran dan marjin pemasaran rendah, maka akan menjadi saluran pemasaran yang paling efisien. Berdasarkan Tabel 7. dapat diketahui bahwa pada saluran pemasaran 4 dianggap sebagai saluran yang paling tinggi tingkat efisiensinya karena memiliki nilai persentase marjin pemasaran yang terkecil dibanding pada saluran lainnya yaitu sebesar 5,85\% dan memiliki nilai farmer's share yang tertinggi yaitu sebesar $94,15 \%$. Saluran pemasaran 4 merupakan saluran terpendek sehingga jagung dapat lebih cepat sampai kepada konsumen tanpa melalui banyak lembaga pemasaran karena semakin banyak lembaga pemasaran yang terlibat maka akan memperbesar marjin pemasaran sehingga bagian yang diterima petani akan semakin kecil. Sedangkan pada saluran 1 dianggap sebagai saluran yang memiliki tingkat efisiensi paling rendah karena memiliki nilai persentase marjin pemasaran yang tertinggi dibanding pada saluran lainnya yaitu sebesar $8,96 \%$ dan memiliki nilai farmer's share yang terendah yaitu sebesar $91,05 \%$.

\section{KESIMPULAN}

Struktur pasar (market structure) yang ada di Kabupaten Wonogiri terdapat kecenderungan yang mengarah pada pasar persaingan tidak sempurna yaitu pasar oligopsoni sehingga pemasaran jagung termasuk dalam kategori tidak efisien.Perilaku pasar (market conduct) menunjukkan bahwa nilai elastisitas transmisi harga $\left(\beta_{1}\right)$ sebesar 0,785 maka $\beta_{1}$ lebih kecil dari 1 (pasar tidak efisien).

Pada kegiatan pemasaran jagung hibrida di Kabupaten Wonogiri terdapat 4 tipe saluran pemasaran. Saluran pemasaran 1 adalah petani $\rightarrow$ pedagang pengumpul desa $\rightarrow$ pedagang besar $\rightarrow$ pabrik pakan. Saluran pemasaran 2 adalah petani $\rightarrow$ pedagang pengumpul kecamatan $\rightarrow$ pedagang besar $\rightarrow$ pabrik pakan. Saluran pemasaran 3 adalah petani $\rightarrow$ pedagang pengumpul kecamatan $\rightarrow$ pedagang luar kota. Saluran pemasaran 4 adalah petani $\rightarrow$ pedagang besar $\rightarrow$ pabrik pakan.

Pada saluran pemasaran 4 merupakan saluran yang paling tinggi tingkat efisiensinya karena memiliki persentase marjin pemasaran terendah. Sedangkan saluran pemasaran 1 merupakan saluran yang paling rendah tingkat efisiensinya karena memiliki nilai persentase marjin pemasaran yang. Hal tersebut menunjukkan bahwa tingkat efisiensi pemasaran jagung di Kabupaten Wonogiri termasuk dalam kategori efisien. 


\section{UCAPAN TERIMA KASIH}

Terimakasih kepada Allah SWT atas segala pertolonganNya dalam penyusunan artikel skripsi saya. Terimakasih kepada Kedua Orang Tua, Dekan, Kepala Program Studi Agribisnis UNS, Dosen Pembimbing, Pihak Instansi dan teman-teman saya yang telah memberikan dukungan, bimbingan, semangat, serta doa yang tidak pernah terputus sehingga saya dapat menyelesaikan artikel ini dengan lancar. Penulis berharap semoga artikel ini bermanfaat sekaligus menambah pengetahuan bagi penulis sendiri khususnya dan pembaca pada umumnya.

\section{DAFTAR PUSTAKA}

Arifin, I. 2007. Membuka Cakrawala Ekonomi. PT Setia Purna Inves, Bandung. Azzaino, Z. 1982. Pengantar Tataniaga Pertanian. Departemen Pertanian. IPB, Bogor. BPS. 2015. Statistik Daerah 2015 Kabupaten Wonogiri. Katalog BPS. Wonogiri.

BPS. 2016. ProvinsiJawa Tengah Dalam Angka. Badan Pusat Statistik Jawa Tengah, Semarang.

BPS. 2017. Kabupaten Wonogiri Dalam Angka. Badan Pusat Statistik Kabupaten Wonogiri, Wonogiri.

Ghozali, I. 2014. Ekonometrika: Teori, Konsep dan Aplikasi dengan IBM SPSS 22. Badan Penerbit Universitas Diponegoro, Semarang.

Irawan, B. 2007. Fluktuasi Harga, Transmisi Harga dan Marjin Pemasaran Sayuran dan Buah. Jurnal Analisis Kebijakan Pertanian 5 (4): 358-373.

Ode, M. D. L. 2012. Etnis Cina Indonesia dalam Politik: Politik Etnis Cina Pontianak dan Singkawang di Era Reformasi 1998-2008. Yayasan Pustaka Obor Indonesia, Jakarta.

Ramkumar. 2001. Costs and Margin in Coconut Marketing: Some Evidence from Kerala. Indian Journal of Agriculture Economic 56 (4): 668-682.

Santoso, S. 2002. Buku Latihan SPSS Statistik Parametrik. Elex Media Komputindo, Jakarta.

Sinaga, S. C. dan Novia, D. 2016. Pemasaran Buah Nenas (Kajian Struktur, Perilaku, dan Penampilan Pasar) Di Desa Kualu Nenas Kecamatan Tambang Kabupaten Kampar. Jurnal Ilmiah Pertanian 13 (1): 38-50.

Singarimbun, M. dan Efendi, S. 2006. Metode Penelitian Survei. LP3ES, Jakarta.

Sudiyono, A. 2001. Pemasaran Pertanian. Universitas Muhamadiyah Malang Press, Malang.

Tangendjaja et al. 2005. Analisis Ekonomi Pertanian Jagung untuk Pakan dalam Ekonomi Jagung Indonesia. Badan Litbang Pertanian. Jakarta.

Tangendjaja, B. dan E. Wina. 2011. Limbah Tanaman dan Produk Sampingan Industri Jagung Untuk Pakan. Balai Penelitian Ternak, Bogor.

Widarjono, A. 2010. Ekonometrika: Pengantar dan Aplikasinya (Disertai Panduan Eviews) Edisi Keempat. UPP STIM YKPN, Yogyakarta.

Yuniarti, T. Umar, Y dan Muslich, M. 2009. Effieciency of Cashew Marketting in the West Lombok Regency (Case Study at the Bayan Production Center). Wacana 12 (1): 204-216. 